\title{
Parasitic castration of Eurhomalea lenticularis (Bivalvia: Veneridae) by a digenetic trematode: quantitative histological analysis
}

\author{
Katherinne Valderrama ${ }^{1}$, Marcelo Oliva ${ }^{2}$, Bernardita Campos ${ }^{3}$, Donald Brown ${ }^{1, *}$ \\ ${ }^{1}$ Departamento de Biología, Instituto de Ciencias Biológicas y Químicas, Facultad de Ciencias, Universidad de Valparaíso, \\ Casilla 5030, Valparaíso, Chile \\ ${ }^{2}$ Facultad de Recursos de Mar, Universidad de Antofagasta, Casilla 171, Antofagasta, Chile \\ ${ }^{3}$ Facultad de Ciencias del Mar, Universidad de Valparaíso, Casilla 5080-Reñaca, Viña del Mar, Chile
}

\begin{abstract}
The clam Eurhomalea lenticularis may be parasitized by digenean trematodes of the family Plagiorchidae, specifically in the gonads (parasitic castration). A quantitative histological analysis of the parasitized gonads demonstrated a significant decrease in gonadal area, in the size of individual acini, and in the numbers of differentiated germ cells compared to unparasitized clams. Castration may be caused by mechanical compression due to trematode sporocyst growth. However, the uniform loss of germ cells in areas without sporocysts suggests that a more generalized mechanism is responsible. We suggest that parasitic castration has a primary effect on the host's neuroendocrine and gametogenic systems that regulate gamete production.
\end{abstract}

KEY WORDS: Bivalve mollusc $\cdot$ Parasitic castration $\cdot$ Histological analysis $\cdot$ Eurhomalea lenticularis Digenea $\cdot$ Trematode $\cdot$ Central Chile

Resale or republication not permitted without written consent of the publisher

\section{INTRODUCTION}

The bivalve mollusk Eurhomalea lenticularis (Sowerby, 1835) is a commercially exploited clam in Chile that can be parasitized by a digenean trematode (Plagiorchidae). Sporocysts of this trematode occur within reproductive tissues, where they cause parasitic castration, a condition defined as a total or partial reduction in gamete production (Sullivan et al. 1985, Emerson-Kagoo \& Ayyakkannu 1994). While this phenomenon has been observed in several species of bivalves (Feng 1988, Cousteau et al. 1990, Jonsson \& André 1992, Lasiak 1991, Santos \& Coimbra 1995, Calvo-Ugarteburu \& McQuaid 1998, Rantanen et al. 1998, Silva et al. 2002) and gastropods (Reader 1973, Sullivan et al. 1985, Oliva 1992, Oliva et al. 1999), the extent of the gonadal damage has not been measured at the histological level. Although the bivalve mytilid Perna perna when parasitized by bucephalid trematodes has marked reduction in reproductive tissue (Silva et al. 2002), no quantitative information about the damage at the germ cell line level is available.

Mechanisms responsible for the gonadal changes due to parasitic castration are postulated to be the result of physical (ingestion, abrasion, or sporocyst pressure) or chemical (secretion of lytic substances, toxins, or endocrinological antagonists) effects by parasites in the gonad (Oliva 1992). Moreover, clams have an integrated neuroendocrine-nerve ganglion-gonad axis that is susceptible to parasitism, resulting in regulatory changes of the axis (Coustau et al. 1991, 1993), documented in gonads with changes in the kinetics of the gametogenesis.

Because previous studies have only qualitatively shown that there is a reduction of the reproductive tissue, we proposed to quantify structural changes in the gonads, due to parasitism, at the histological level. To test if parasitic castration produced in Eurhomalea lenticularis is due to mechanical damage or the result 
of alteration in the neuroendocrinological system of the clam, we quantified the variation between germ cell number in the presence and absence of sporocysts.

\section{MATERIALS AND METHODS}

Sample processing and histology. To determine the prevalence of the parasite, a total of 1702 clams was obtained from June 1995 to February 1998 by diving on a natural bank located at El Algarrobo inlet, central Chile $\left(33^{\circ} 20^{\prime} \mathrm{S}, 71^{\circ} 40^{\prime} \mathrm{W}\right)$. They were transported live to the laboratory, and at least 1 random sample of 30 clams was processed each month (1034 in total; the remaining clams were dissected and observed under the stereoscopic microscope to determine the presence of the parasite) using routine histological techniques (Gabe 1968). After $1 \mathrm{~h}$ fixation in Bouin Hollande fluid to harden the tissues, serial transverse sections, $5 \mathrm{~mm}$ thick, were made of the visceral mass containing the gonad. After fixation in fresh fixative for $48 \mathrm{~h}$, the thick sections were washed in tap water for $24 \mathrm{~h}$, dehydrated in graded ascending concentrations of ethanol to $100 \%$, cleared in butanol and embedded in Paraplast Plus (Oxford ${ }^{\circledR}$ ). Histological sections of $5 \mu \mathrm{m}$ thickness were made at different levels through the tissue at $300 \mu \mathrm{m}$ intervals, deparaffinized, and rehydrated in a decreasing series of ethanol concentrations, and stained by a trichrome staining method. Briefly, the sections were stained in Harris hematoxylin solution for $75 \mathrm{~s}$ and rinsed in running tap water for $10 \mathrm{~min}$, followed by a quick rinse in distilled water. Next, they were stained with a mixture of $0.5 \%$ Erythrosin- $0.5 \%$ Orange G for $30 \mathrm{~min}$, and quickly rinsed in distilled water. They were immersed in $0.5 \%$ phosphotungstic acid for $10 \mathrm{~min}$, and again quickly rinsed in distilled water. Finally, they were stained in $1 \%$ Aniline blue for $75 \mathrm{~s}$ and immediately dehydrated in 3 consecutive baths of $95 \%$ ethanol followed by 3 baths in $100 \%$ ethanol (Arteta trichrome stain; López et al. 1982). After clearing in xylenes, the slides were coverslipped using Canada balsam (López et al. 1982).

Morphological and quantitative observations were made on tissues from parasitized and unparasitized clams collected for histology, using bright-field light microscopy on a Leitz Orthoplan instrument equipped with a Cohu camera Model 4812. Images were digitized using LG-3 PCI frame grabber w/4Mb-NTSC standard (Scion Corporation) and analyzed using an $\mathrm{NIH}$ (National Institute of Health) image 1.6 program (free access at http://rsb.info.nih.gov/nih-image).

To determine the effect of the parasites on the gonad, the total acinar area was compared with the acinar area occupied by trematodes, with the individual acinar area, and with the germ cell line of parasitized clams. Control preparations included homologous samples similarly prepared from unparasitized clams.

Quantification of total acinar area. Each tissue section was completely scanned in both males and females, guided by reference coordinates of the microscope at a magnification of $125 \times$. Images obtained from each microscope field were superposed over a fixed area $\left(244695 \mu^{2}\right)$. Areas occupied by acini and areas occupied by parasites were then measured. These measurements were expressed as a percentage of the total area observed. Differences between parasitized and 'control' unparasitized clams were examined using an analysis of variance (ANOVA) following angular transformation (Steel \& Torrie 1988).

Quantification of individual acinar areas. We measured 100 acini in each clam at a magnification of 50×. The results were expressed as means $\pm 1 \mathrm{SD}$ and the significance of observed differences between parasitized and non-parasitized clams were evaluated using ANOVA.

Quantification of the germ cell line. The different types of cells in the germ cell line of female clams were classified as previtellogenic premeiotic oocytes (PPO), previtellogenic oocytes in meiotic prophase (POM), attached vitellogenic oocytes (AVO), pedunculate vitellogenic oocytes (PVO), and free vitellogenic oocytes (FVO). In each of 3 histological sections from parasitized and unparasitized samples, 5 random counts were made for oocytes in different stages of development, as described above, at a magnification of $312.5 \times$ and aided by a grid placed in the eyepiece of the microscope. Only cells containing a nucleus or germinative vesicle and nucleolus were counted as representative of 1 cell. Data were expressed as a mean of counts in each section ( 3 sections). Each datum was transformed $(\sqrt{n}+0.5)$, and a Student $t$-test was applied to the independent samples (Sokal \& Rohlf 1995) to determine if significant differences existed between parasitized and unparasitized clams. Since cells of the germ cell line in males were very small in size, the stereological method of Weibel (1979) was applied, using a Weibel reticle of 100 points in an area of $43515{\mu \mathrm{m}^{2}}^{2}$. The grid was superimposed over digitized microscopic images of sections (3 per clam), and germ cells for the early germ line (EGL: spermatogonia and spermatocytes) and advanced germ line (AGL: spermatids and spermatozoa) which intersected the lines of the grid were counted. Cells that fell on either the left or bottom outer perimeter lines of the grid (forbidden axes) or in open spaces within the grid were not counted. Each final result was expressed as a mean \pm SD. Differences between the means of these groups were analyzed using a $t$-test for independent samples following angular transformation. 


\section{RESULTS}

From 1702 clams obtained between June 1995 and February 1998, 31 were parasitized. Seasonality of infections was not observed, and prevalence was very low $(1.82 \%)$. From the sample of 1034 clams processed for histology, only 16 clams (prevalence $1.64 \%$ ) were heavily parasitized and had compromised gonads in the condition described below.

\section{Structure of unparasitized and parasitized gonads}

The unparasitized gonad of Eurhomalea lenticularis showed an organizational pattern as described by Campos \& Brown (unpubl. data). Briefly, large numbers of gametogenic acini exist, surrounded by the digestive system. Hemolymphatic spaces and vessels occur among the acini, and connective tissue-muscle bundles, which interconnect with the connective tissue-muscle wall underlying the epidermal tissue. There is continuity between the acini and gonoducts that are covered by a simple ciliated epithelium. The acini show a basal lamina and variable shape and size (passing through a multi-lobulate form), depending on their stage of activity. Basal and lumen regions can be observed in both sexes. The early germ cell line is observed in the basal region, which in the females includes oogonia, PPO, POM, and AVO (Fig. 1); and spermatogonia, spermatocytes, and undifferentiated round spermatids in males (Fig. 2). Advanced cells from the germ cell line are found in the central (lumen) region; in females these include PVO and FVO (Fig. 1) and in males, elongated spermatids undergoing cytodifferentiation, with their tails toward the lumen and spermatozoa filling the region (Fig. 2).

The general organization of the parasitized gonad in females (Figs. 3 \& 5) and males (Figs. 4 \& 6) was similar to that of unparasitized clams. Acini compressed by the presence of parasite sporocysts took on the appearance of what in unparasitized clams would appear to be normal gonadal regression. This appearance can be described as the decrease in size of gonadal acini observed after partial evacuation gametes, and in some cases by signs of cytolysis of germ cells together with the presence of hemocytes (Fig. 5).

\section{Variations in total and individual acinar area}

The average area occupied by the acini of both parasitized males and females was significantly less than that recorded for unparasitized clams (Tables 1 \& 2), even though within individual clams the variation in the acinar area was high (large standard deviation), because the areas observed at random showed varying numbers of acini. In general, these results were related to a decrease in the individual acinar area, which was much more significant in parasitized females than in males compared with unparasitized clams, through the different seasons (Tables 1 \& 2). Females in winter 1995 showed individual acinar areas to have decreased to $81 \%$, which was not significant; in females collected in fall 1996 and in summer 1998, the decrease reached $50 \%$, and the same measurement in spring 1995 showed a further reduction to only $17 \%$ of the original acinar area. These later reductions were statistically significant (Table 1).

Although in males there was a significant reduction in the total acinar area, the parasitized male obtained in summer 1998 showed no changes in individual acinar area (Table 2).

\section{Variations in germ cell line}

Parasitized females showed significantly higher numbers of previtellogenic oocytes and fewer free vitellogenic oocytes than unparasitized clams (Table 3). Although the parasitized female collected in winter 1995 showed a non-significant decrease in individual acinar area, this decrease was significantly consistent with the decrease in FVO in the various seasons, including the PVO in winter and spring 1995 (cf. Tables 1 \& 3). In contrast, the greater quantity of PPO and POM occurred in areas and on borders of reduced acini. The only parasitized female collected in spring 1995 was interesting as it demonstrated an increase in previtellogenic oocytes and, particularly, POM (Fig. 5), although an absence of any type of vitellogenic oocytes was expected (Fig. 5, Table 3). With this exception, differences in the numbers of AVO were not more significant than in unparasitized clams. Parasitized males had a significantly lower value for EGL and AGL than unparasitized clams (Table 4). This was related to the decrease in gonadal area occupied by the acini, and with the individual acinar area (cf. Tables $2 \& 4$ ).

However, in spring 1996, differences in EGL and AGL were notable and significant, declining to 55 and $46 \%$ respectively (Table 4 ; Figs. 4 \& 6).

\section{DISCUSSION}

The gonads of parasitized male and female Eurhomalea lenticularis were, in general, organized, like those of unparasitized clams, but were occupied by sporocysts producing a significant decrease in the gonadal area represented by the acini. Although the acini appeared to be simply compressed by an abun- 


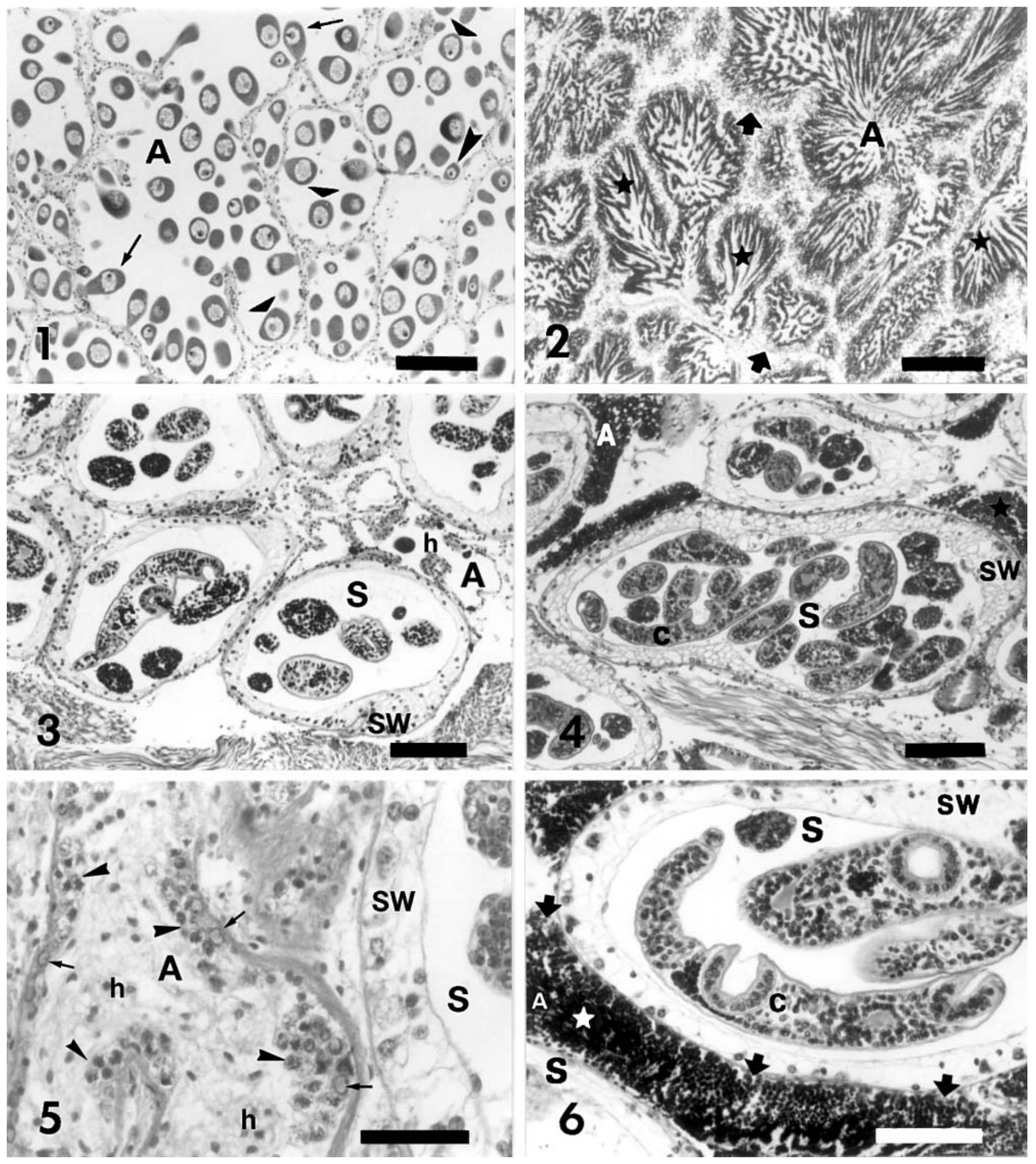

Figs. 1-6. Eurhomalea lenticularis. Photomicrographs of transverse histological sections of gonad. Fig. 1. Unparasitized female, large-sized normal acini. Fig. 2. Unparasitized male, large-sized normal acini. Figs. 3-6. Parasitized gonad: Fig. 3. Female, numerous sporocists interspersed with reduced-size acini. Fig. 4. Male, numerous sporocysts interspersed with reduced-size acini. Fig. 5. Acini at high magnification, showing groups with numerous previtellogenic oocytes in meiotic prophase, and oogonia in interphase. Fig. 6. High magnification of male gonadal acinus with diminished advanced germinal line between 2 sporocysts. A: gonadal acinus; C: cercaria; S: sporocyst; SW: sporocyst wall. Female germ cell line: (־) oogonia with interphasic nucleus; $(\longrightarrow$ previtellogenic oocytes in meiotic prophase (PPO); $(\longrightarrow)$ attached vitellogenic oocyte (AVO); $(\longleftarrow)$ pedunculate vitellogenic oocyte $(\mathrm{PVO})_{i}(\mathbf{)})$ free vitellogenic oocyte (FVO). Masculine germ cell line: ( $)$ early germ cell line (EGL); ( ) advanced germ cell line (AGL); (h) hemocytes. Scale bars in Figs. $1-4=150 \mu \mathrm{m}$, in Fig. $5=50 \mu \mathrm{m}$, in Fig. $6=100 \mu \mathrm{m}$ 
Table 1. Eurhomalea lenticularis. Variations in mean percentage of total area occupied by gonadal acini and in mean area of individual acini in parasitized and unparasitized females

\begin{tabular}{|c|c|c|c|c|c|c|c|c|c|}
\hline \multirow[t]{2}{*}{ Clam condition } & \multirow{2}{*}{$\begin{array}{l}\text { No. of } \\
\text { clams }\end{array}$} & \multirow{2}{*}{$\begin{array}{l}\text { No. of } \\
\text { areas }\end{array}$} & \multicolumn{3}{|c|}{ - Total acinar area (TAA) } & \multirow[b]{2}{*}{$\begin{array}{l}\text { No. of } \\
\text { areas }\end{array}$} & \multicolumn{2}{|c|}{ - Area individual acinus (AIA) } & \multirow[b]{2}{*}{$\mathrm{p}$} \\
\hline & & & $\%(\bar{x} \pm \mathrm{SD})$ & F & $\mathrm{p}$ & & $\mathrm{mm}^{2}(\bar{x} \pm \mathrm{SD})$ & $F$ & \\
\hline \multicolumn{10}{|l|}{ Winter 1995} \\
\hline Parasitized & 1 & 45 & $29.51 \pm 21.33$ & \multirow[t]{2}{*}{57.91} & \multirow[t]{2}{*}{$<0.0001$} & 100 & $5.67 \cdot 10^{-2} \pm 6.33 \cdot 10^{-2}$ & \multirow[t]{2}{*}{1.475} & \multirow[t]{2}{*}{0.226} \\
\hline Unparasitized & 1 & 31 & $67.10 \pm 14.58$ & & & 100 & $6.96 \cdot 10^{-2} \pm 8.44 \cdot 10^{-2}$ & & \\
\hline \multicolumn{10}{|l|}{ Spring 1995} \\
\hline Parasitized & 1 & 24 & $15.09 \pm 12.81$ & \multirow[t]{2}{*}{132.32} & \multirow[t]{2}{*}{$<0.0001$} & 100 & $0.93 \cdot 10^{-2} \pm 1.31 \cdot 10^{-2}$ & \multirow[t]{2}{*}{53.101} & \multirow[t]{2}{*}{$<0.0001$} \\
\hline Unparasitized & 1 & 18 & $75.70 \pm 16.18$ & & & 100 & $5.30 \cdot 10^{-2} \pm 5.85 \cdot 10^{-2}$ & & \\
\hline \multicolumn{10}{|l|}{ Fall 1996} \\
\hline Parasitized & 1 & 21 & $33.54 \pm 19.08$ & \multirow[t]{2}{*}{89.76} & \multirow[t]{2}{*}{$<0.0001$} & 100 & $3.54 \cdot 10^{-2} \pm 3.41 \cdot 10^{-2}$ & \multirow[t]{2}{*}{10.881} & \multirow[t]{2}{*}{0.001} \\
\hline Unparasitized & 1 & 32 & $82.26 \pm 12.08$ & & & 100 & $6.22 \cdot 10^{-2} \pm 7.38 \cdot 10^{-2}$ & & \\
\hline \multicolumn{10}{|l|}{ Summer 1998} \\
\hline Parasitized & 1 & 41 & $24.59 \pm 25.01$ & \multirow[t]{2}{*}{103.64} & \multirow[t]{2}{*}{$<0.0001$} & 100 & $3.36 \cdot 10^{-2} \pm 4.17 \cdot 10^{-2}$ & \multirow[t]{2}{*}{14.239} & \multirow[t]{2}{*}{$<0.001$} \\
\hline Unparasitized & 1 & 46 & $71.21 \pm 12.09$ & & & 100 & $6.36 \cdot 10^{-2} \pm 6.77 \cdot 10^{-2}$ & & \\
\hline
\end{tabular}

Table 2. Eurhomalea lenticularis. Variations in mean percentage of total area occupied by gonadal acini and in mean area of individual acini in parasitized and unparasitized males

\begin{tabular}{|c|c|c|c|c|c|c|c|c|c|}
\hline \multirow[t]{2}{*}{ Clam condition } & \multirow{2}{*}{$\begin{array}{l}\text { No. of } \\
\text { clams }\end{array}$} & \multicolumn{4}{|c|}{ _ Total acinar area (TAA) } & \multirow[b]{2}{*}{$\begin{array}{l}\text { No. of } \\
\text { areas }\end{array}$} & \multicolumn{2}{|c|}{ - Area individual acinus (AIA) } & \multirow{2}{*}{$\bar{p}$} \\
\hline & & $\begin{array}{l}\text { No. of } \\
\text { areas }\end{array}$ & $\%(\bar{x} \pm \mathrm{SD})$ & $F$ & $\mathrm{p}$ & & $\mathrm{mm}^{2}(\bar{x} \pm \mathrm{SD})$ & $F$ & \\
\hline \multicolumn{10}{|l|}{ Spring 1996} \\
\hline Parasitized & 1 & 61 & $10.33 \pm 9.0$ & \multirow[t]{2}{*}{394.42} & \multirow[t]{2}{*}{$<0.0001$} & 100 & $2.82 \cdot 10^{-2} \pm 2.26 \cdot 10^{-2}$ & \multirow[t]{2}{*}{6.821} & \multirow[t]{2}{*}{$<0.01$} \\
\hline Unparasitized & 1 & 27 & $76.00 \pm 12.06$ & & & 100 & $3.85 \cdot 10^{-2} \pm 3.24 \cdot 10^{-2}$ & & \\
\hline \multicolumn{10}{|l|}{ Spring 1997} \\
\hline Parasitized & 1 & 28 & $47.91 \pm 25.43$ & \multirow[t]{2}{*}{18.84} & \multirow[t]{2}{*}{$<0.0001$} & 100 & $2.92 \cdot 10^{-2} \pm 2.68 \cdot 10^{-2}$ & \multirow[t]{2}{*}{7.572} & \multirow[t]{2}{*}{$<0.001$} \\
\hline Unparasitized & 1 & 28 & $74.92 \pm 12.85$ & & & 100 & $4.26 \cdot 10^{-2} \pm 4.08 \cdot 10^{-2}$ & & \\
\hline \multicolumn{10}{|l|}{ Spring 1998} \\
\hline Parasitized & 1 & 31 & $18.78 \pm 17.82$ & \multirow[t]{2}{*}{83.33} & \multirow[t]{2}{*}{$<0.0001$} & 100 & $3.34 \cdot 10^{-2} \pm 3.36 \cdot 10^{-2}$ & \multirow[t]{2}{*}{0.001} & \multirow[t]{2}{*}{0.97} \\
\hline Unparasitized & 1 & 27 & $68.62 \pm 11.0$ & & & 100 & $3.32 \cdot 10^{-2} \pm 2.89 \cdot 10^{-2}$ & & \\
\hline
\end{tabular}

dance of sporocysts in the interacinar space, there was a real reduction in their size, as they contained fewer than normal numbers of differentiated germ cells. In all parasitized clams, gonadal tissue and germ cells were present and the gonad could be recognized. This evidence supports the hypothesis that E. lenticularis was suffering parasitic castration from mechanical effects and from an alteration of the kinetics of gametogenesis. This work is the first attempt to quantify the cells of the germ cell line in female and male clams to determine the effect of the parasite on the kinetics of the gametogenesis as an expression of changes in the neuroendocrine regulatory system.

The effects of parasitic castration have been mentioned for several species of bivalve molluscs in which sporocysts occupied the gonadal area of the host. Infection in mussels has been described as varying degrees of gonadal atrophy culminating in total gonadal destruction by bucephalid trematode sporocysts (Lasiak 1991), degenerative follicles and blocked follic- ular channels (Santos \& Coimbra 1995), normal gametogenesis impaired or prevented by Proctoeces maculatus (see Feng 1988), or total absence of genital follicles resulting from Prosorhynchus squamatus infestation (see Coustau et al. 1990). Infestation by Cercaria cerastodermae I, a trematode parasite of the cockle Cerastoderma edule, was very pronounced in the gonads and foot, and in some individuals the gonads were totally disintegrated by the parasites and few or no gametes were detected (Jonsson \& André 1992). In the freshwater semelparous clam Pisidium amnicum, 3 digenean parasite species castrated their hosts and no clams containing parasites and embryos were found, semelparity being produced by the parasites (Rantanen et al. 1998). Also in the gastropods Concholepas concholepas (Oliva et al. 1999) and Ilyanassa obsoleta (Sullivan et al. 1985), castration by Digenea have been described as a decrease in the sizes of the acini and of the gonad, although no information was obtained on the effects on the germ cell line. Pressure exerted by the growing 


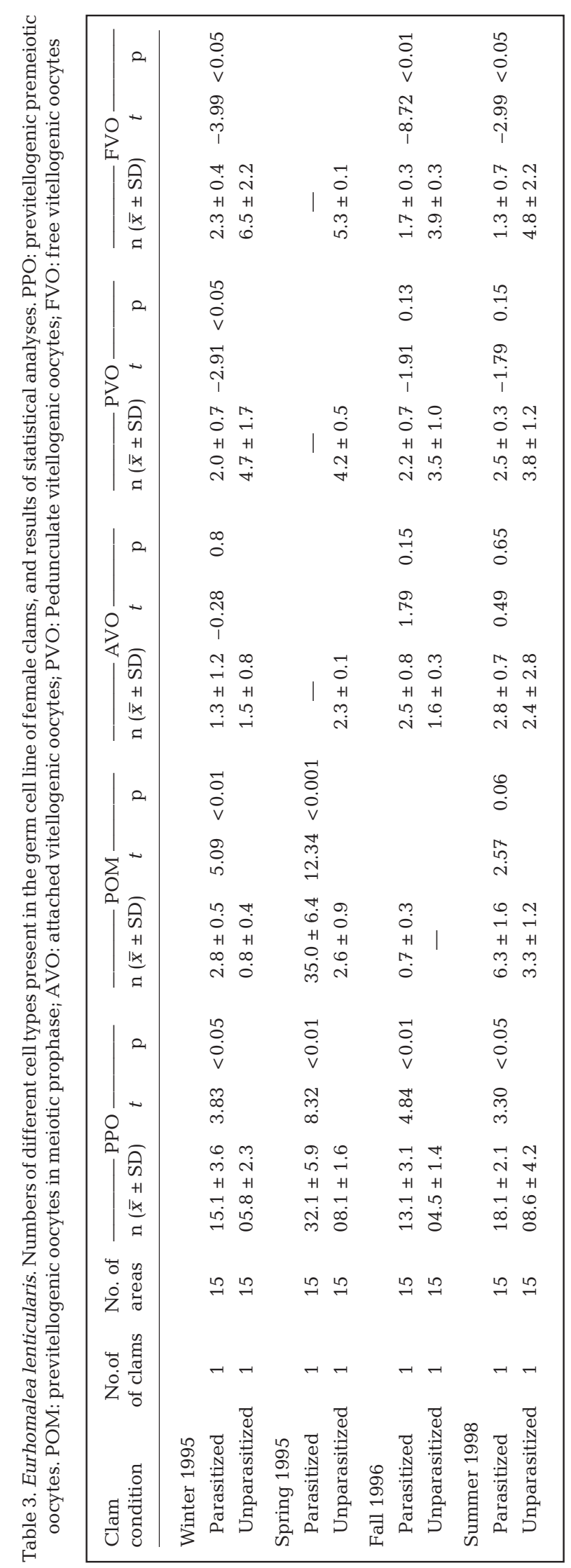

sporocysts on the acini (Sullivan et al. 1985) produced mechanical effects (i.e. deformation) in this tissue, readily observable in the microscope. In Bythinia tentaculata parasitized by Cercaria helvetica XII, the seminiferous tubules of infected males contained few normal-appearing germ cells and germ cells in different phases of degeneration (Reader 1973). The degenerative changes in these species have been postulated as a consequence of pressure due to the sporocysts combined with toxic effects of secretions possibly produced by the parasite, and autolysis due to malnutrition produced by blockage of the hemocoelomic spaces (Reader 1973).

In mytilid bivalves from southern Chile, the extent of infection by a bucephalid trematode was scored, employing a qualitative 5-point scale (Lasiak 1991). According to the amount of host tissue occupied by the parasite in mussels with Stage 5 of the infection, the gonadal tissues appeared to have been replaced totally by a densely packed mass of branching sporocysts (Lasiak 1991). In the mytilid Perna perna, the degree of infection was quantified by stereology, which showed that the area representing reproductive tissue regression varied according to the quantity of parasite tissues (sporocists) or according the infection intensity (Silva et al. 2002). In heavier infections (around $80 \%$ of infected mussels), reproductive tissue degeneration was intense, gametogenesis was drastically impaired, and partial or complete mussel castration occurred (Silva et al. 2002). Although in mytilids parasitic castration is the main effect produced by trematode infection, 2 different trematode species can affect reproduction (bucephalid sporocysts) or growth (Proctoeces sp.) (Calvo-Ugarteburu \& McQuaid 1998).

Gametogenesis is a complex process by which undifferentiated stem germ cells produce differentiated and species-specific gametes for fertilization. It comprises a mitotic proliferation stage in the germ cells (oogonia and spermatogonia), a meiotic maturation stage with a long prophase (oocytes and spermatocytes), and an important cytodifferentiation stage (oocytes and spermatids). The existence of each stage implies regulation by the neuroendocrine complex that may be altered by exogenous or endogenous factors such as parasites.

In parasitized females of Eurhomalea lenticularis, apparently oogonial proliferation (not differentiable between oogonia and PPO) increased markedly, as did previtellogenic oocytes in the meiotic prophase, seen as an unusually large increase in the female in spring 1995. These results suggest that the proliferative activity has been affected by the parasite, indicated by the large increase in previtellogenic oocytes. In parasitized males, the decrease in the early germ cell line (EGL) would indicate that the spermatogonial proliferation step was inhibited, suggesting a differential 
Table 4. Eurhomalea lenticularis. Percentage of germ cell line present in gonads of male clams, and results of statistical analyses. EGL = early germ line; AGL = advanced germ line

\begin{tabular}{|c|c|c|c|c|c|c|c|c|}
\hline \multirow[t]{2}{*}{ Clam condition } & \multirow{2}{*}{$\begin{array}{l}\text { No. of } \\
\text { clams }\end{array}$} & \multirow{2}{*}{$\begin{array}{l}\text { No. of } \\
\text { areas }\end{array}$} & \multicolumn{3}{|c|}{ EGL } & \multirow{2}{*}{$\%(\bar{x} \pm \mathrm{SD})$} & \multirow{2}{*}{$\begin{array}{r}\mathrm{AGL} \\
t\end{array}$} & \multirow[b]{2}{*}{$\mathrm{p}$} \\
\hline & & & $\%(\bar{x} \pm \mathrm{SD})$ & $t$ & $\mathrm{p}$ & & & \\
\hline \multicolumn{9}{|l|}{ Spring 1996} \\
\hline Parasitized & 1 & 15 & $17.5 \pm 0.5$ & -3.602 & $<0.05$ & $24.7 \pm 10.0$ & -3.602 & $<0.05$ \\
\hline Unparasitized & 1 & 15 & $31.7 \pm 4.9$ & & & $54.0 \pm 9.4$ & & \\
\hline \multicolumn{9}{|l|}{ Spring 1997} \\
\hline Parasitized & 1 & 15 & $30.4 \pm 4.2$ & -4.935 & $<0.01$ & $32.1 \pm 2.0$ & -2.177 & 0.095 \\
\hline Unparasitized & 1 & 15 & $46.6 \pm 3.8$ & & & $36.5 \pm 2.8$ & & \\
\hline \multicolumn{9}{|l|}{ Summer 1998} \\
\hline Parasitized & 1 & 15 & $20.0 \pm 0.9$ & -6.239 & $<0.01$ & $31.8 \pm 9.9$ & -3.578 & $<0.05$ \\
\hline Unparasitized & 1 & 15 & $25.3 \pm 1.2$ & & & $53.8 \pm 3.4$ & & \\
\hline
\end{tabular}

inhibitory effect of the parasite on the male gonad, or at some level of the neuroendocrine complex. In Mytilus edulis, a mitogenic factor produced by the cerebral ganglion stimulates proliferation of the oogonia and spermatogonia (Mathieu et al. 1988). In Crassostrea gigas and $M$. edulis, 5 neuropeptide variants belonging to the family of gonadotropic releasing hormones (GnRH) are effective in stimulating the synthesis of gonadal DNA by up to $140 \%$ in gonadal suspensions. Immunoreactive GnRH-like cells were found in the central nervous system of the mytilid (Pazos \& Mathieu 1999). However, the existence of endogenous systems and parasite-induced antimitotic activities that inhibit reproduction have been partially characterized in this mytilid, parasitized by the trematode Prosorhynchus squamatus (Coustau et al. 1993).

During the meiotic maturation phase, the oocytes become arrested in the diplotene phase of the long prophase to assume the process of cytodifferentiation characteristic of active vitellogenesis, leading to accumulation of yolk. Vitellogenesis is interrupted in parasitized Eurhomalea lenticularis, which is evidenced by the increase of previtellogenic oocytes and the decrease in free vitellogenic oocytes. These clams may be responding with the production of more oocytes, which are unable to culminate the vitellogenic stage. Since the amount of attached and pedunculate vitellogenic oocytes does not vary, and free vitellogenic oocytes are significantly reduced, this suggests that the parasites are employing the energy for vitellogenesis for their own benefit. In the scallop Mizuhopecten yessoensis, the steroids stradiol, progesterone, and testosterone are involved in the stimulation of mitotic activity during the stage of sexual repose, as well as being involved in growth and vitellogenesis of female germinal cells (Varaksina \& Varaksin 1991), and hence in energy allocation for reproduction. In the freshwater clam Anodonta piscinalis, the trematode Rhipidocotyle fennica (Bucephalidae) can selectively use the energy that the clam normally allocates to its own reproduc- tion; energy allocated to developing eggs and glochidia larvae is redirected to production of parasite cercariae (Jokela et al. 1993). However, in the mytilid Perna perna, 2 parasites affected different components of the host energy budget, Proctoeces sp. affected growth but not reproduction, and bucephalid sporocysts affected mainly reproduction but not growth (Calvo-Ugarteburu \& McQuaid 1998). When the mussel Mytilus edulis were submitted to starvation, large deposits of glycogen were observed in the parasite while the host glycogen reserves were almost depleted (Dennis et al. 1974).

Monoamines, neuropeptides, and steroids have important roles in the control of gametogenesis and reproduction in molluscs, although the available information is currently contradictory and some activities are not well defined for these substances (Smith \& Croll 1997). This study showed that gonadal neurochemistry may be altered by a parasite. Parasites inducing or producing neuroendocrine or genetic alterations in their hosts is a well-documented phenomenon (Schallig et al. 1991, Reid et al. 1998), and parasitic interference with neurohormonal control systems may be a general characteristic of parasite-host interactions in molluscs.

Although in our study the prevalence of the parasite was low, besides changes in gonadal acinar areas, dramatic changes in female and male germ cell lines, not only in total numbers but also in particular cell types, occurred. The alteration in early germ cell number indicates the parasite's interference in germ cell line proliferation. However, another mechanism may operate in this system to deprive the clam of energy reserves for vitellogenesis or spermatid cytodifferentiation. This could explain the changes in differentiated germ cells, promoting growth of the sporocysts within the clam gonad. Our ongoing research in this parasitehost system is directed to finding mollusc populations with a high prevalence of the parasite, in order to test the hypothesis that the parasite causes neuroendocrine 
interference in the production of gametes within the host (as proposed earlier; Coustau et al. 1991, 1993, Schallig et al. 1991), and that the mechanical effects observed are secondary effects of the growth of the parasite.

Acknowledgements. This work is part of the undergraduate thesis of the first author. We thank the Regional Government (V Region) for awarding a Regional Interest Thesis Fellowship to K.V. We thank Dr. Louis DiSalvo for suggestions and the English translation of the manuscript. This research was supported by Grant No. 20-95 from the Dirección de Investigación y Postgrado, Universidad de Valparaíso, Chile to B.C. and D.I.B.

\section{LITERATURE CITED}

Calvo-Ugarteburu G, McQuaid CD (1998) Parasitism and invasive species: effects of digenetic trematodes on mussels. Mar Ecol Progr Ser 169:149-163

Coustau C, Combes C, Maillard C, Renaud F, Delay B (1990) Prosorhynchus squamatus (Trematoda) parasitosis in the Mytilus edulis-Mytilus galloprovincialis complex: specificity and host-parasite relationships. In: Perkins FO, Cheng TC (eds) Pathology in marine science. Academic Press, San Diego, p 291-298

Coustau C, Renaud F, Delay B, Robbins I, Mathieu M (1991) Mechanisms involved in parasitic castration: in vitro effects of the trematode Prosorhynchus squamatus on the gametogenesis and the nutrient storage metabolism of the marine bivalve mollusc Mytilus edulis. Exp Parasitol 73: $36-43$

Coustau C, Robbins I, Delay B, Renaud F, Mathieu M (1993) The parasitic castration of the mussel Mytilus edulis by the trematode parasite Prosorhynchus squamatus: specificity and partial characterization of endogenous and parasiteinduced antimitotic activities. Comp Biochem Physiol 104: 229-233

Dennis EA, Sharp M, Douglass (1974) Carbohydrate reserves and phosphatase activity in the mollusc-trematode relationship of Mytilus edulis L. and Proctoeces maculatus (Loos, 1901) Odhner, 1911. J Helminthol 48:1-14

Emerson-Kagoo I, Ayyakkannu K (1994) Pathological changes caused by parasites in Chicoreus ramosus L. Phuket mar biol Cent Spec Publ 13:225-228

Feng SL (1988) Host response to Proctoeces maculatus infection in the blue mussel, Mytilus edulis L. J Shellfish Res 7: 118

Gabe M (1968) Techniques histologiques. Masson et Cie, Paris

Jokela J, Uotila L, Taskinen J (1993) Effect of the castrating trematode parasite Rhipidocotyle fennica on energy allocation of fresh-water clam Anodonta piscinalis. Funct Ecol 7:332-338

Jonsson R, André C (1992) Mass mortality of the bivalve Cerastoderma edule on the Swedish west coast caused by infestation with the digenean trematode Cercaria cerastodermae I. Ophelia 36:151-157

Editorial responsibility: Albert Sparks, Seattle, Washington, USA
Lasiak T (1991) Bucephalid trematode infections in mytilid bivalves from the rocky intertidal of southern Chile. J Molluscan Stud 58:29-36

López M, Leyton C, Graf M (1982) Técnicas de histología y citología. Departamento de Biología Celular y Genética, Facultad de Medicina, Universidad de Chile, Santiago

Mathieu M, Robbins I, Lenoir F (1988) A gonial mitosis-stimulating factor in cerebral ganglia and hemolymph of the marine mussel, Mytilus edulis L. Gen Comp Endocrinol 72:257-263

Oliva M (1992) Parasitic castration in Fissurella crassa (Archaeogastropoda) due to an adult digenea, Proctoeces lintoni (Fellodistomidae). Mem Inst Oswaldo Cruz 87:37-42

Oliva M, Olivares A, Diaz C, Pasten M (1999) Parasitic castration in Concholepas concholepas (Gastropoda: Muricidae) due to a larval digenean in northern Chile. Dis Aquat Org 36:61-65

Pazos AJ, Mathieu M (1999) Effects of five natural gonadotropin-releasing hormones on cell suspensions of marine bivalve gonad: stimulation of gonadal DNA synthesis. Gen Comp Endocrinol 113:112-120

Rantanen JT, Valtonen ET, Holopainen IJ (1998) Digenean parasites of the bivalve mollusc Pisidium amnicum in a small river in eastern Finland. Dis Aquat Org 33:201-208

Reader TA (1973) Histological and ultrastructural studies on the testis of Bithynia tentaculata (Mollusca: Gastropoda), and on effects of Cercaria helvetica XII (Trematoda: Digenea) on this organ. J Zool 171:541-561

Santos AMT, Coimbra J (1995) Growth and production of raftcultured Mytilus edulis L., in Ria de Aveiro: gonad symbiotic infestation. Aquaculture 132:195-211.

Schallig HDFH, Sassen MJM, Hordijk PL, Jong-Brink M de (1991) Trichobilharzia ocellata: influence of infection on the fecundity of its intermediate snail host Lymnaea stagnalis and the cercarial induction of the release of schistosomin, a snail neuropeptide antagonizing female gonadotropic hormones. Parasitology 102:85-91

Silva PM, Magalhães ARM, Barracco MA (2002) Effects of Bucephalus sp. (Trematoda: Bucephalidae) on Perna perna mussels from a culture station in Ratones Grande Island, Brazil. J Invertebr Pathol 79:154-162

Smith SA, Croll RP (1997) 4: Mollusca. In: Adams TS (ed) Reproductive biology of invertebrates, Vol VIII. Progress in reproductive endocrinology, 1st edn. John Wiley \& Sons, Chichester, p 61-151

Sokal R, Rohlf F (1995) Biometry: the principles and practice of statistics in biological research, 3rd edn. WH Freeman, New York

Steel RGD, Torrie JH (1988) Bioestadística: principios y procedimientos, 2 edn. McGraw-Hill, Mexico City

Sullivan J, Cheng TC, Howland K (1985) Studies on parasitic castration: castration of Ilyanassa obsoleta (Mollusca: Gastropoda) by several marine trematodes. Trans Am Microsc Soc 104:154-171

Varaksina GS, Varaksin AA (1991) Effect of stradiol, progesterone and testosterone on oogenesis in Yezo scallop. Biol Morya 3:61-68

Weibel ER (1979) Stereological methods, Vol 1. Practical methods for biological morphometry. Academic Press, London

Submitted: December 26, 2002; Accepted: October 21, 2003 Proofs received from author(s): April 26, 2004 